\title{
1 The effects of harvest regime, irrigation, and salinity on stem \\ 2 lignocellulose concentrations in alfalfa (Medicago sativa $\mathbf{L}$.)
}

3

4 Adam H. Warnke and Christopher T. Ruhland*

5

6

7

8 *Corresponding author:

9

10

11

12

13

14

15

16

17

18
Christopher T. Ruhland, Department of Biological Sciences, TS-

242 Trafton Sciences Center, Minnesota State University,

Mankato, MN 56001, USA

Email: christopher.ruhland@mnsu.edu

Phone: +1 507 389-1323

Fax: $\quad+1507389-2788$ 
ABSTRACT

Alfalfa (Medicago sativa L.) is a potential candidate for cellulosic ethanol production

21 due to its high biomass, perennial-habit, relationship with nitrogen-fixing bacteria, and other co-

22 products. We examined the effects of harvest regime, irrigation, and salinity on stem

23 lignocellulose concentrations in alfalfa during the 2010 and 2011 growing seasons in Southern

24 Minnesota. Stem cellulose, hemicellulose and lignin concentrations, and theoretical ethanol

25 yields were examined in eight alfalfa cultivars with full-bud and 50\%-flower harvest regimes,

26 irrigation, and salinity as applied treatments. Plants received weekly applications of (1) $1.27 \mathrm{~cm}$

27 of well water (“fresh water;" $\left.0.75 \mathrm{dS} \mathrm{m}^{-1}\right)$, (2) $1.27 \mathrm{~cm}$ of saline water ( $\mathrm{NaCl}$; "brackish water";

$285.0 \mathrm{dS} \mathrm{m}^{-1}$ ) or (3) ambient precipitation ("rainfed"). Holocellulose concentrations reached the

29 highest values during the full bud (2010) and 50\% flower (2011) harvest regimes with

30 concentrations averaging $45 \%$. Theoretical ethanol yields were generally higher for the $50 \%$ -

31 flower harvest regime, suggesting the longer growth period increased holocellulose

32 concentrations while not being hindered by more lignin in older stems. Alfalfa growing under

33 brackish-water treatments had 1.3 to $6.1 \%$ more holocellulose than those receiving irrigation or

34 ambient precipitation over two growing seasons. Lignin concentrations across all treatments

35 were almost $23 \%$ lower during the second growing season. Interestingly, plants growing under

36 brackish-water treatments had higher holocellulose to lignin ratios and higher theoretical ethanol

37 yields during both field seasons suggesting that moderate levels of salt may stimulate

38 holocellulose concentrations. 
40 keywords: alfalfa, biofuel, cellulose, feedstocks, hemicelluloses, holocellulose, lignin

41

42 abbreviations: ADF, acid detergent fiber; ADL, acid detergent lignin; ANOVA, analysis of

43 variance; DRI, disease and pest resistance index; FD, fall dormancy; NDF, neutral detergent

44 fiber; WSI, winter survival index

45

46

47

48

49

50

51

52

53

54

55

56 


\section{1. Introduction}

At the current rate of consumption, world crude oil reserves are predicted to deplete in

59 approximately 40 years, hence, it has become essential to find methods of processing renewable

60 and sustainable raw materials for conversion into fuel (Maheshwari, 2008). Increasing global

61 population has further magnified this necessity. Shifting society's reliance away from petroleum

62 to renewable biomass resources is viewed as an important contribution to the development of a

63 sustainable industrial society and to an effective management of greenhouse gas emissions

64 (Rugauska et al., 2006). Biofuels have been recognized as a renewable, cost-effective alternative 65 to petroleum-based liquid fuels. The starch-based ethanol industry has grown very rapidly in the

66 United States, however, most experts see the need for the development of a lignocellulose-based

67 biofuels industry to meet the current Federal Biofuels Mandate for displacing 30\% of petroleum

68 consumption by 2030 (McCaslin and Miller, 2007).

A major source for biofuel comes from polysaccharides created by the photosynthetic

70 process. These polysaccharides can be divided into two major groups: starch, a storage

71 polymer, consisting of glucose monomers with $\alpha(1 \rightarrow 4)$ and $\alpha(1 \rightarrow 6)$ glycoside linkages, and

72 cellulose, a structural polymer, consisting of glucose monomers with $\beta(1 \rightarrow 4)$ glycoside

73 linkages. In addition to cellulose, plant secondary cell walls also contain appreciable amounts of

74 lignin. Lignin is a complex phenolic polymer that is closely linked to polysaccharides in the cell

75 wall and hinders the degradation of these polysaccharides to simple sugars, which is required for

76 fermentation to ethanol (Chapple et al., 2007).

Ethanol production from plant-produced polysaccharides has been commercialized using

78 starch from corn grains. The starch in corn kernels is much easier to break down than cellulose 
79 and hemicelluloses ("holocellulose") in the cell wall of biomass material. In this sense corn

80 starch is converted to glucose and fermented to produce ethanol. However, there are several

81 economic problems associated with the production of ethanol from corn grain. The increased

82 demand for corn may impact the world's food stock and possibly drive up the prices of corn-

83 based products. In addition, the large amounts of fossil fuels used to process starch-based

84 ethanol are expensive and release greenhouse gases. The vision of a future bio-based industry

85 includes the simultaneous production of biofuels, bioelectricity, and bioproducts using not only

86 corn grain and soybean oil, but also a host of renewable lignocellulose-based feedstock (Walsh et

87 al., 2007). Lignocellulose-based ethanol is particularly promising because it can take advantage

88 of biotechnology to dramatically reduce costs, is derived from low-cost and abundant feedstocks,

89 can achieve high yields, and is typically environmentally friendly (Wyman, 2007). However,

90 there are problems with commercializing lignocellulose-based ethanol due to the high initial

91 capital cost. Separating cellulose from lignin during processing is costly and produces

92 potentially harmful bi-products.

Corn stover and cobs, as well as wheat straw are obvious annual crop residue feedstocks

94 for lignocellulose ethanol production. Switchgrass (Panicum virgatum), a native C4 perennial

95 forage grass, is often mentioned as a leading perennial energy crop candidate. Drought

96 tolerance, low fertility requirements, and the ability to grow on marginal soils will likely make

97 switchgrass an important component in a biofuel cropping system in some regions (McCaslin

98 and Miller, 2007). Ultimately, identifying plants that have high holocellulose to lignin ratio is

99 an essential step when determining what species are best suited for ethanol production. This 
100 study will focus on the use of alfalfa (Medicago sativa) as a potential crop in a biofuels

101 production system.

Alfalfa has promise as a feedstock for production of ethanol and other industrial materials

103 because of its high biomass yields, perennial-habit, relationship with nitrogen-fixing bacteria and

104 other valuable co-products (Jung and Engels, 2002). It grows on soils with a pH level of 6.5-7.0

105 and adequate levels of $\mathrm{P}$ (60 to $100 \mathrm{~kg} \mathrm{ha}^{-1}$ ) and $\mathrm{K}$ (180 to $250 \mathrm{~kg} \mathrm{ha}^{-1}$ ) are optimal for

106 subsequent years of production (McKenzie, 2005). Varietal selection of alfalfa is typically based

107 upon the winter survival index (WSI), fall dormancy (FD), and disease and pest resistance index

108 (DRI). Alfalfa cultivars with lower WSI ratings will have the ability to survive potentially harsh

109 winters. Fall dormancy is the measure of how tall an alfalfa plant grows after the last cutting and

110 before going dormant for the season. The DRI is based upon selecting cultivars with superior

111 disease resistance to ensure a long productive stand. The WSI rating is very important in

112 Minnesota due to potentially harsh winters. A cultivar that can withstand severe low

113 temperatures is crucial when selecting alfalfa.

Alfalfa can be harvested for biomass in the year of planting and provides $\mathrm{N}$ to the soil for

115 use by subsequent cereal crops in rotation (Sheaffer et al., 2000). The growth stages of alfalfa

116 are well known in this sense, harvest schedules for leaf protein are determined upon them for

117 ruminant livestock feed. Typical harvest schedules produce three to four cutting per growing

118 season. An advantage of using alfalfa for lignocellulose biofuel production, compared to other

119 crops, is the ability to easily separate leaves and stems to produce co-products (Samac et al.,

120 2006). Alfalfa leaves typically have two to three times the crude protein of the stems while

121 stems typically have two to three times the crude fiber of the leaves (Shinners et al., 2007). The 
122 high protein leaf portion could be utilized as an animal feed, while the high lignocellulose stem 123 portion could be used as a biofuel feedstock (McCaslin and Miller, 2007).

Using alfalfa for biofuels would require research to determine the optimal holocellulose

125 to lignin ratio for ethanol production. Recommended harvest schedules for modern alfalfa

126 cultivars in a lignocellulose biofuel system are unknown because the comparative value of leaf

127 and stem components is likely to vary with energy consumption and livestock feed prices

128 (Sheaffer et al., 2000). Based on previous research (Lamb et al., 2007), mature alfalfa stems had

129 higher concentrations of lignocellulose on a seasonal, yield adjusted basis under the biomass

130 management system than the hay system. Typically as alfalfa ages, the stems become more

131 lignified and have lower cellulose concentrations (Sanderson and Wedin, 1988). Previous

132 research has focused on plant density along with harvest intervals. In this study, we focused on

133 harvest intervals across the same plant density. Determining the optimal harvest schedule for

134 protein and lignocellulose concentrations will be a vital step for the future of alfalfa as a biofuel

135 feedstock. However, to achieve maximum biomass yields of alfalfa, irrigation may be needed in

136 several productive regions of the world.

Crop yield depends on the amount of irrigation water and its distribution (Montazar and

138 Sadeghi, 2008). Alfalfa has a high water requirement compared to other commonly grown crops

139 because it has a long growing season, a deep root system, and high biomass yields (Krogman and

140 Hobbs, 1965; Bauder et al., 1992). Drought stress on alfalfa can inhibit cell elongation, reduce

141 photosynthesis, interfere with nutrient uptake, and alter plant regulators (Saeed and El-Nadi,

142 1997). Saeed and El-Nadi (1997) observed that alfalfa stem density, stem height and leaf size

143 decreased when soil water deficits occurred. 
Root and shoot growth in alfalfa is restricted by increased salinity (Esechie et al., 2002),

145 presumably due to changes in water uptake (Munns et al., 2006) and salt toxicity (Munns, 2002)

146 resulting in reductions in growth and yield (Allakhverdiev et al., 2000). For long-term

147 productivity, perennial crops such as alfalfa must be able to adapt to increasing heterogeneous

148 root zone salinity (Vaughan et al., 2002). The relationship between alfalfa growth and water use,

149 under an irrigated system, is very important in determining the effects of salinity on stem

150 lignocellulose concentrations.

The purpose of this study was to analyze the effects of harvest regime, irrigation, and

152 salinity on stem lignocellulose concentrations in alfalfa. Irrigation and salinity are both factors

153 that affect plant growth and there is little data on how they affect stem lignocellulose

154 concentrations. In combination with a harvest schedule these two factors should provide

155 valuable information for alfalfa's potential as a biofuel feedstock.

\section{2. Materials and methods}

\subsection{Plot establishment and cultivar selection}

The field experiment was conducted during three growing seasons (2009 - 2011) on an agricultural field located 2.5 miles west of Geneva, Minnesota $\left(43^{\circ} 81^{\prime} \mathrm{N} \times 93^{\circ} 32^{\prime} \mathrm{W}\right)$. The soil

161 at this location is a Webster Clay Loam-113 (Carlson et al., 1980) and has a pH of 6.5.

162 Phosphorous and potassium concentrations averaged $\geq 65$ and $\geq 190 \mathrm{~kg} \mathrm{ha}^{-1}$, respectively (data

163 not shown). Precipitation was collected by a rain gauge at the field site. The site was tilled

164 using a 3.05-m field cultivator at a depth of 0.10 to $0.15 \mathrm{~m}$. Alfalfa cultivars were planted using 165 a 2.0-m Tye drill with 0.2-m row spacing. 
Eight cultivars, two harvest regimes (full-bud and 50\%-flower), and irrigation/salinity

167 regimes (irrigated with fresh water, brackish water and rainfed) were compared. We selected

168 cultivars of alfalfa based upon the winter survival index (WSI), fall dormancy (FD), and disease

169 and pest resistance (DRI). The eight cultivars used in this study included: 1-WL 363HQ:

170 Waterman-Loomis Seed Company (WSI-1.6 and FD-4.8), 2-Viking 357: Viking Seeds (WSI-2.5

171 and FD-3.4), 3-L447HD: Wolf River Valley Seeds (WSI-2.0 and FD-3.7), 4-Enforcer: Allied

172 Seed (WSI-2.2 and FD-3.5), 5-Viking 3100: Viking Seeds (WSI-2.6 and FD-3.0), 6-Fontanelle

173 Hybrid - Ovation 2: Fontanelle Hybrids (WSI-2.3 and FD-3.4), 7-Gold Country 24/7: Gold

174 Country Seed (WSI-2.5 and FD-3.8), and 8-Iroquois: Iroquois Seed (WSI and FD-unknown).

175 All cultivars had sufficient disease and pest resistance ratings. Cultivars 1-5 were obtained from

176 Albert Lea Seed in Albert Lea, Minnesota. Cultivars 6 to 8 were obtained from a local dairy

177 farmer. These cultivars are all well established in Minnesota and are suitable for this research.

A complete random block in a split-plot arrangement design was applied with two or

179 three harvest regimes as whole plots and eight alfalfa cultivars, irrigation, and salinity treatments

180 as subplots. There were two replicates at the experimental location (Supplementary Information

181 A). Plots were 3.66 by $5.49 \mathrm{~m}$ (cultivar) and subplots were 1.83 by $3.66 \mathrm{~m}$ (treatment). A

182 seeding rate of $14.6 \mathrm{~kg} \mathrm{ha}^{-1}$ resulted in stand densities for all plots $\approx 450$ plants $\mathrm{m}^{-2}$. Weeds were

183 controlled with a post-emergence application of $292 \mathrm{~mL} \mathrm{ha}^{-1}$ of ammonium salt of imazethapyr

184 (Pursuit) \{( \pm )-2-[4,5-dihydro-4-methyl-4-(1-methylethyl)-5-oxo-1H-imidazol-2-yl]-5-ethyl-3-

185 pyridinecarboxylic acid\}. Plots were sprayed as needed with S-Cyano (Mustang Max) [(3-

186 phenoxyphenyl) methyl (+) cis/trans 3-(2,2-dichloroethenyl)-2,2 dimethylcyclopropane

187 carboxylate] for potato leafhopper [Empoasca fabae (Harris)] control. 


\subsection{Irrigation and salinity application}

Irrigation was applied using a 492-L water tank located in the back of a pickup truck. Water was supplied from a local well ( $\mathrm{pH}$ 6.9). Applications were applied with an 18.9 L per minute pump attached by rubber hoses to a hand held sprinkler. The rain feature on the attached sprinkler was used in order to deliver a consistent application. Each subplot had 5 rain gauges (one in each corner and one in the center of the plot) to ensure accurate treatment applications. For irrigation treatments, each cultivar subplot was irrigated with either $1.27 \mathrm{~cm}(83.3 \mathrm{~L})$ application of well water (“fresh water;" $\left.0.75 \mathrm{dS} \mathrm{m}^{-1}\right)$ or brackish water $\left(5.0 \mathrm{dS} \mathrm{m} \mathrm{m}^{-1}\right)$ every 7 to 10 days, depending on local weather patterns. Salinity measurements were performed with a conductivity meter (model: Field Scout Direct Soil EC Meter; Spectrum Technologies Inc., Aurora IL, USA) capable of measuring salts in both soil and liquid samples. In order to simulate water with high salinity, $\mathrm{NaCl}$ (Fisher Scientific, Pittsburgh, PA, USA) was added until an electrical conductivity of $5.0 \mathrm{dS} \mathrm{m}^{-1}$ was obtained for the brackish water treatments. Fresh- and brackish-water treatments were applied to individual subplots a total of eight and seven times for a total application of 666 and $583 \mathrm{~L} \mathrm{subplot}^{-1}$ for the 2010 and 2011 growing season, respectively. Soil salinity was also measured directly at these times using the soil conductivity meter approximately 45-60 min after treatment applications. During each survey, five replicate electrical conductivity measurements were made at random locations in each of the subplots at a depth of $5 \mathrm{~cm}$ directly in the rooting zone. Direct soil electrical conductivity measurements were then extrapolated to saturated-paste extract values following manufacturer guidelines.

\subsection{Forage sampling and sample preparation}


Forage was harvested in 2009 prior to treatment application using a sickle-bar mower

210

211

212

213

214

215

216

217

218

219

220

221

222

(Jari Mowers, Mankato,MN, USA) at $0.5 \mathrm{~cm}$ above the soil line. Subplots were harvested in the second and third years of production (2010 and 2011) when alfalfa reached full-bud (>50\% of stems having one or more buds) and 50\%-flower (66-100\% of stems having one or more flower). The full-bud regime was harvested three times per season and the 50\%-flower regime was harvested twice per season. Each subplot had ten plant samples collected at each growth stage.

Herbage yields were measured by harvesting a $0.91-$ by-3.66 m strip of forage to a 5 -cm height from the center of each plot with a hand operated sickle bar mower. At harvest, ten random subsamples were collected for analysis. Samples were placed in labeled paper bags and oven dried at $60^{\circ} \mathrm{C}$. The remaining non-sampled plants were cut at 5-cm above ground level and then bailed and removed from the plots. Each subsample was manually separated into leaf and stem fractions. The remaining portions of the stems were ground with a Wiley mill through a 1$\mathrm{mm}$ screen in preparation for constituent analysis.

\subsection{Constituent analyses}

A fiber analyzer (model A200; ANKOM Technology, Macedon NY, USA) was used to estimate concentrations of cellulose, hemicellulose and lignin in dried samples following Van Soest (1991). Dried samples (0.5 g) were placed into pre-weighed filter bags and analyzed with acid detergent fiber (ADF) solution (20 g cetyl trimethylammonium bromide to $1 \mathrm{~L} 1.00 \mathrm{~N}$ $\left.\mathrm{H}_{2} \mathrm{SO}_{4}\right)$ at $100^{\circ} \mathrm{C}$ for 60 min. Samples were rinsed with hot $\mathrm{dH}_{2} \mathrm{O}$ and acetone, dried, and placed in a drying oven $\left(102^{\circ} \mathrm{C}\right)$ overnight. Samples were then cooled, weighed and \%ADF (cellulose + lignin) was calculated. 
The second sub-sample for each treatment was then used to estimate neutral detergent

231 fiber (NDF). Dried samples (0.5 g) were placed into pre-weighed filter bags and analyzed with

232 NDF solution (sodium lauryl sulfate, ethylendiamine-tetraacetic disodium salt dihydrate, sodium

233 tetraborate decahydrate, sodium phosphate dibasic, anhydrous and triethylene glycol). Heat-

234 stable bacterial alpha amylase and sodium sulfite was added to the analyzer, afterwards samples

235 were incubated at $100^{\circ} \mathrm{C}$ for $75 \mathrm{~min}$. Samples were then rinsed twice with alpha amylase

236 solution, then once in acetone and dried overnight $\left(102^{\circ} \mathrm{C}\right)$. Samples were then cooled, weighed

237 and \%NDF (cellulose, hemicellulose + lignin) was calculated.

238

239

240

241

242
Acid detergent lignin (ADL) was estimated on samples used for ADF analysis. Samples were immersed in $72 \% \mathrm{H}_{2} \mathrm{SO}_{4}$ for $3 \mathrm{~h}$ and agitated every $30 \mathrm{~min}$. Samples were then rinsed in $\mathrm{dH}_{2} \mathrm{O}$ and acetone, dried overnight $\left(102^{\circ} \mathrm{C}\right)$ and weighed. Samples were then ashed in a muffle furnace $\left(525^{\circ} \mathrm{C}\right)$ for $3 \mathrm{~h}$, cooled and weighed. Cellulose concentrations were calculated as $\% \mathrm{ADF}$ - \%ADL, and hemicellulose concentration were calculated as \% NDF - \%ADF.

Theoretical ethanol yields were determined using assumed cellulose and hemicellulose conversion and fermentation efficiencies following Badger (2002). Fermentation assumptions were based on $1000 \mathrm{~kg}$ of dried biomass. Ethanol yields from glucose were calculated for alfalfa stems using the average cellulose concentrations and ethanol yields from xylose were calculated for alfalfa stems using the average hemicellulose concentrations.

\subsection{Statistical analyses}

A general linear model procedure was used with a one-way analysis of variance (ANOVA; SigmaPlot, 2008) to examine differences in cellulose, hemicellulose, lignin, and 
251 theoretical ethanol yields between harvest regimes and treatments (rainfed, brackish and fresh 252 water) during the 2010 and 2011 growing seasons. The least significant difference (LSD) post-

253 hoc test was used to compare individual means. A two-way ANOVA was used to analyze

254 differences in cellulose, hemicellulose, lignin, and theoretical ethanol yields between the harvest

255 regime + treatment (rainfed, brackish and fresh water) and the cultivar differences during the 2562010 and 2011 growing seasons, followed by post-hoc LSD test (SigmaPlot, 2008). Differences 257 were considered significant at the $P<0.05$ level unless otherwise noted.

259 3. Results

2603.1 Precipitation patterns and soil salinity

261 During the 2010 growing season, the field site received $91.9 \mathrm{~cm}$ of precipitation which is $26217.4 \mathrm{~cm}$ more than the historical average from 2001-2009 (Supplementary Information B). The 263 months of June and September received 60.0 and 57.3\% more precipitation than the historical 264 averages for these months, respectively. During the 2011 growing season the field site received $26548.8 \mathrm{~cm}$ of precipitation which is $25.7 \mathrm{~cm}$ less than the historical average from the same period. 266 Precipitation during August, September, and October was 84.0, 88.4, and 87.9\% lower than the 267 historical averages from 2001-2009 for those months, respectively (Supplementary Information 268 B).

269 At the start of the experiment (2009), soil salinity measurements at our site ranged 270 between 0.97 to $1.61 \mathrm{dS} \mathrm{m} \mathrm{m}^{-1}$. In 2010 and 2011 , soil salinity measurements ranged from 0.99 to $2715.69 \mathrm{dS} \mathrm{m}^{-1}$ and 0.94 to $7.15 \mathrm{dS} \mathrm{m}^{-1}$, respectively (Supplementary Information B). Due to the 
272 large variance in soil salinity measurements, we did not detect any consistent differences

273 between treatments over the course of the experiment.

2753.2 Harvest regimes and irrigation treatments

In 2010, cellulose concentrations in alfalfa averaged $36.7 \%$ and did not differ between

277 the full-bud and 50\%-flower harvest regimes. However, in 2011 average cellulose

278 concentrations were 5.4\% higher in plants at the 50\%-flower harvest than those at full-bud

279 ( $\mathrm{p}<001$; Figure 1A). Interestingly, cellulose concentrations decreased $4.6 \%$ at the full-bud

280 harvest and increased $1.6 \%$ at the 50\%-flower harvest after two seasons ( $<<0.01$; Figure $1 \mathrm{~A})$.

281 Cellulose concentrations were highest in alfalfa plants in brackish-water treatments for both

282 years $(\mathrm{p}<0.05$; Figure $2 \mathrm{~A})$. These plants had $2.1-3.5 \%$ (2010) and $4.1-2.4 \%$ (2011) more

283 cellulose than those in the rainfed and fresh-water treatments, respectively. Alfalfa growing in

284 brackish-water treatments generally had higher cellulose concentrations in both full-bud and $28550 \%$-flower harvest in both 2010 and 2011 (Figure 1A).

287 at the 50\%-flower harvest for 2010 and 2011, respectively ( $<<0.05$; Figure 1B). Alfalfa plants

288 growing under brackish and fresh-water treatments had 9.2 and 8.1\% (2010) and 14.1 and $18.0 \%$

289 (2011) higher hemicellulose concentrations than those in rainfed treatments, respectively

290 ( $\mathrm{p}<0.01$; Figure 2B). These differences were typically more pronounced during the full-bud

291 harvest during both years (Figure 1B). 
Holocellulose (cellulose + hemicellulose) concentrations were mainly a function of

293 cellulose content and mirrored these values across seasons, harvest regimes and irrigation

294 treatments. Holocellulose concentrations averaged $45.1 \%$ and did not differ between the full-bud 295 and 50\% flower harvests in 2010. However in 2011, plants sampled at the 50\%-flower harvest

296 had 3.5\% more holocellulose than those at the full-bud harvest $(\mathrm{p}<0.01$; Figure $1 \mathrm{C})$. Similar to

297 cellulose, holocellulose concentrations at the full-bud harvest decreased 4.7\% from 2010 to 2011

298 (Figure 1C) and were highest in the brackish-water treatments both growing years $(\mathrm{p}<0.01$;

299 Figure 2C).

300

Lignin concentrations were $13.9 \%$ higher in plants harvested at full bud compared to

301 those at the 50\%-flower stage in $2010(\mathrm{p}<0.01)$, but there were no differences observed between

302 these two harvest regimes in 2011 (Figure 1D). Lignin concentrations decreased 28.7 and

$303 \quad 15.5 \%$ in plants sampled at the full-bud and 50\%-flower regimes, respectively, from the 2010 to

$3042011(\mathrm{p}<0.01 ;$ Figure 1D). There were no differences in lignin content between the irrigation

305 treatments in 2010, but in 2011 alfalfa in the brackish-water treatments had $2.3 \%$ less lignin in

306 their stems (Figure 2D).

Surprisingly, the overall holocellulose to lignin ratio (holocellulose:lignin) was greater in

3082011 than in 2010 ( $<<0.01$; Figure 1E). There were no differences in this ratio between harvest

309 regimes in 2011, but in 2010 plants in the 50\%-flower regime had a $12.8 \%$ higher

310 holocellulose:lignin than those harvested at full bud $(\mathrm{p}<0.01$; Figure $1 \mathrm{E})$. The ratio tended to be

311 higher in plants under brackish-water treatments during both 2010 and $2011(\mathrm{p}=0.09$ and $\mathrm{p}<0.05$,

312 respectively; Figure 2E). 
313

314

315

316

317

318

319

320

321

322

323

324

325

326

327 328 lignin content.

329

\subsection{Cultivar selection}

The average cellulose concentrations of the eight cultivars during the 2010 ranged from 35.1 to $38.0 \%$. In 2011 concentrations of cellulose ranged from 35.5 to $37.2 \%$ (Figure $3 \mathrm{~A}$ ). The Gold Country cultivar had the highest cellulose concentration for both years. Hemicellulose concentrations for all cultivars ranged from 7.8 to $9.2 \%$ over the course of two years. The Iroquois and WL363HQ consistently had high concentrations of hemicellulose in both 2010 and 2011 ( $p<0.05$; Figure 3B). Holocellulose concentrations of the eight cultivars ranged from 43.4 to $46.4 \%$ during both seasons (Figure 3C). Holocellulose concentrations were consistently high in the Gold Country cultivar during both seasons, mainly due to increased cellulose content.

Lignin concentrations in alfalfa stems of the eight cultivars ranged from 14.0 to $18.4 \%$ over the course of the experiment (Figure 3D). The Enforcer cultivar consistently had low concentrations of lignin during both years, and all eight cultivars experienced significant reductions in overall lignin content from the 2010 to 2011 ( $\mathrm{p}<0.01$; Figure 3D). There were few differences in the holocellulose:lignin ratio in either year (Figure 3E), but the ratio was once again reduced from 2010 to 2011 in all eight cultivars $(\mathrm{p}<0.01)$, mainly due to the reduction in

\subsection{Theoretical ethanol yields.}

Total theoretical ethanol yields were mainly a function of cellulose concentrations. Cellulose ethanol yields comprised 84.2 to $85.5 \%$ of total holocellulose yields. Total theoretical ethanol yields across all treatments averaged 146.3 and 143.0 in 2010 and 141.6 and $145.8 \mathrm{~L} \mathrm{t}^{-1}$ in 2011 for plants at the full-bud and 50\% flower stage, respectively (Table 1). Total theoretical 
334 ethanol yields decreased $4.3 \%$ for plants sampled at the full-bud harvest regime from 2010 to $3352011(\mathrm{p}<0.01)$, but increased $1.2 \%$ for plants sampled at the 50\%-flower harvest $(\mathrm{p}<0.01$; Table 336 1). In a manner similar to cellulose concentrations, total theoretical ethanol yields were highest 337 under brackish-water treatments during both years ( $\mathrm{p}<-0.01$; Figure 4; Table 1).

339 ( $<<0.05$; Table 2) while the Viking 357 had the highest yields in 2011 and averaged $146.7 \mathrm{~L}$

340 (p<0.05; Table 2). Both Iroquois (2010) and Viking 357 (2011) cultivars had high hemicellulose 341 concentrations (Figure 3B) and the higher conversion efficiencies of hemicellulose compared to 342 that of cellulose contributed to their higher total theoretical ethanol yields.

\section{4. Discussion}

345 Growing season, harvest regime, irrigation, and salinity caused effects on stem lignocellulose 346 concentrations in alfalfa. Harvest regime affected stem lignocellulose concentrations but results 347 varied significantly between growing seasons. It appears that precipitation patterns had a major 348 influence on the effects of irrigation and salinity on stem lignocellulose concentrations. Plants 349 under supplemental irrigation had higher lignocellulose concentrations and this effect was more 350 pronounced during the dry period (August-October) in the 2011 growing season. However, over 351 the duration of this study no signs or symptoms of drought stress occurred. 
355 harvested after the 2010 and 2011 growing seasons followed similar trends for hemicellulose 356 concentrations. Hemicellulose concentrations of the plants sampled at the $50 \%$-flower harvest 357 regime in both growing seasons decreased from the full-harvest regime. Plants harvested at the 358 full-bud harvest regime had significantly higher lignin concentrations than those harvested at the $35950 \%$-flower harvest regime in 2010. However, there were no significant differences in lignin 360 concentrations in plants sampled during the 2011 growing season. While maturity is the single 361 most important factor impacting stem lignocellulose concentrations in alfalfa, growth 362 environment causes some additional shifts in stem lignocellulose allocation concentrations. 363 Unfortunately these environmental impacts are complex and difficult to predict (Samac et al., 364 2006). Sanderson and Wedin (1988) found substantially higher lignocellulose concentrations in 365 alfalfa stems during one year, however, the same plots harvested the following year showed a 366 small difference between harvest regimes. In this study temperature and moisture were not 367 independently evaluated. In studies that have evaluated temperature and moisture separately, the 368 major effect of moisture stress alone appeared to be on the amount of cell wall accumulated by 369 alfalfa plants as opposed to changes in cell wall composition (Samac et al., 2006). We found 370 similar results in the holocellulose to lignin ratios between harvest regimes and growing seasons. 371 During the 2010 growing season, there was an increase in the holocellulose to lignin ratio 372 between the full-bud to the 50\%-flower harvest regimes. However, in 2011, there was no 373 significant difference between harvest regimes, but the holocellulose: lignin ratio in this case 374 increased 24.8 and $14.5 \%$ for plants sampled at the full-bud and 50\%-flower harvest regimes, 375 respectively, from the 2010 to the 2011 growing season (Figure 1A). Total estimated ethanol 376 yields also varied by harvest regime and growing season. Lamb et al. (2007) found that alfalfa 
377 grown under a biomass-type management system (50\%-flower harvest regime) increased

378 lignocellulose concentrations by $4 \%$ and could increase hypothetical ethanol yields by $6.5 \%$.

379 During the 2011 growing season the plants sampled at the 50\%-flower harvest regime had a

$3803.2 \%$ increased lignocellulose concentrations over the full-bud harvest regime which increased

381 theoretical ethanol yields by $4.0 \%$ (Table 1). However, during the 2010 growing season there

382 was a decrease in theoretical ethanol yield from the plants sampled at the full-bud to the 50\%-

383 flower harvest regime. Potential ethanol yields associated with stem-maturity harvests appear to

384 be quite variable. Lamb et al. (2014) found that potential yields were higher at late-flower

385 harvests, while Rock et al. (2009) observed similar patterns similar to ours; where stem

386 lignocellulose concentrations in alfalfa exhibited year by harvest interactions with no clear

387 pattern. Both studies concluded that industries that wish to utilize alfalfa for lignocellulose

388 ethanol production must be prepared to deal with significant feedstock quality variation due to

389 macro-environment fluctuations such as location, harvest date, irrigation regime and cultivar

390 selection.

This study was conducted in a natural field setting with the rainfed plots receiving

392 ambient amounts of precipitation. During the 2010 growing season the field site received 23\%

393 more precipitation than the historical average (Supplementary Information B). The fresh- and

394 brackish-water treatments received an additional $5.0 \mathrm{~cm}$ of well water per harvest regime

395 depending on local precipitation patterns. Irrigation did not have a significant effect on stem

396 lignocellulose concentrations during the 2010 growing season although the hemicellulose

397 concentrations showed a significant increase as compared to rainfed plots. However, plants

398 growing in brackish-water treatments had significantly higher holocellulose concentrations 
399 (cellulose and hemicellulose), holocellulose to lignin ratios, and the theoretical ethanol yields

400 (Figures 2; 4). In 2011, which was a drier year (34\% less precipitation than the historical

401 monthly average), the addition of fresh and brackish water appear to have contributed to plants

402 with higher holocellulose concentrations (cellulose and hemicellulose) over the rainfed treatment

403 (Figures 2; 4). Deetz et al. (1994) found that alfalfa plants that grew under water-deficit

404 conditions had reduced stem lignocellulose concentrations, reduction which was most likely the

405 result of delayed maturity and decreased cell wall concentrations. Interestingly, alfalfa growing

406 under brackish-water treatments had higher holocellulose to lignin ratios (and higher theoretical

407 yields) during both growing season suggesting that moderate levels of salt may stimulate

408 holocellulose concentrations. Moderate levels of salinity can reduce root and shoot growth

409 (Esechie et al., 2002), alter photosynthesis (Khan et al. 1994) and modify overall plant water

410 relations (Serraj and Drevon, 1998). However, the effects of salt on cell wall composition in

411 alfalfa has only recently been examined. In other agronomic species such as tomato, moderate

412 levels of salt increased lignin deposition and the number of lignified xylem cells (Quiroga et al.,

413 2000; Sanchez-Aguayo et al., 2004). In short term growth chamber studies examining alfalfa,

414 the application of salt increased the upregulation of several groups of cellulose synthase genes

415 (Guerriero et al., 2014) and genes involved in lignin biosynthesis (Behr et al., 2015). Our results

416 agree with these findings and it appears that strengthening of the cell wall is a common response

417 to salinity and other abiotic stresses (Tenhaken, 2015). Alfalfa growing under our brackish-

418 water treatments had higher holocellulose concentrations but lower lignin concentrations during

419 the 2011 growing season. These findings could be significant because selecting species with 
420 high holocellulose to lignin ratios will be an important characteristic when selecting feedstocks

421 for ethanol production.

422

423

424

425

426

427 the highest total theoretical ethanol yield during the 2010 growing season (Table 2); it was

428 obtained from a local farmer and the WSI and FD rankings were unknown. Typically, Iroquois

429 alfalfa is a non-genetically modified cultivar with average yields (Manske and Goetz, 1982);

430 during the 2011 growing season it produced the lowest total theoretical ethanol yield (Table 2).

431 The Gold Country cultivar also had very high total theoretical ethanol yields during both

432 growing seasons. Cultivar selection did not seem to have a pronounced effect on stem

433 lignocellulose concentrations in alfalfa. High yielding cultivars (Gold Country) did not have a

434 significantly greater holocellulose to lignin ratio or total theoretical ethanol yields compared to

435 typical non-genetically modified alfalfa (Iroquois). Research on biomass yields and forage

436 nutrition quality could prove beneficial for cultivar selection in the future if alfalfa is used as a

437 feedstock for lignocellulose ethanol production.

Feedstocks for the sole purpose of biofuel production must be sustainable, carbon neutral

439 and have little environmental impact. Alfalfa has a reduced requirement for nitrogen fertilizer,

440 increased environmental protection and a well-known cropping system which gives it an

441 advantage over other comparable feedstocks. In many scenarios alfalfa leaves and stems would 
442 be separated for lignocellulose ethanol production. Generally, management systems have 443 emphasized harvesting alfalfa forage at immature growth stages to maximize the leaf component 444 and crude protein concentrations; although a biomass production system would make the stem 445 component as valuable as the leaf yield (Lamb et al., 2003; 2014). Separating the leaves from 446 the stems in the field would create a more viable system than separation facilities that have been 447 proposed by other researchers (Arinze et al., 2003; Downing et al., 2004). Another improvement 448 on the alfalfa cropping system would be to seed the alfalfa in the fall after the current crop has 449 been harvested, which has the potential to increase the first year alfalfa yields. Genetic 450 improvements could also increase alfalfa's value as biomass feedstock. Genetically decreasing 451 the concentration of lignin in alfalfa stems would decrease fermentation costs and in turn 452 increase ethanol yields. Crops such as Miscanthus spp., Populus spp., and switchgrass (Panicum virgatum) could 454 be used for lignocellulose ethanol production as an alternative to corn-based feedstocks. Unlike 455 alfalfa, many of the proposed crops do not have well-established cropping systems and farmers 456 may be reluctant to invest in these systems. While corn stover has a potentially high ethanol 457 yield (227 $\mathrm{L} \mathrm{t}^{-1}$; Badger 2002), it also has high energy inputs and is associated with large 458 amounts of erosion and $\mathrm{N}$ leaching (Vadas et al., 2008). Alfalfa has a high $\mathrm{N}$ use efficiency but 459 also has a high water requirement (Krogman and Hobbs, 1965), especially when used as hay, 460 which has contributed to the increase in irrigation in the United States in recent years (Howell, 461 2001). In our study, theoretical ethanol yields ranged from 134-150 $\mathrm{L} \mathrm{t}^{-1}$, which is comparable to 462 findings from natural wetland (136 $\left.\mathrm{L} \mathrm{t}^{-1}\right)$ and prairie $\left(150 \mathrm{~L} \mathrm{t}^{-1}\right)$ systems (Ruhland et al. 2011). A 463 recent cost-benefit analysis by Vadas et al., (2008) has demonstrated that a corn-alfalfa system 
464 increases energy production efficiency and decreases energy inputs with only a slight reduction

465 in net energy yield per hectare over a continuous corn scenario. However, in their analysis they

466 assumed only two alfalfa cuttings per season, and in many scenarios three to four cuttings are

467 possible. Alfalfa rotations would decrease the need for $\mathrm{N}$ inputs and help reduce soil erosion. In

468 the future, the sustainability of a cellulosic-based biofuel industry will likely depend on a wide

469 range of factors that will need to account for reductions in product yield based on plant stress, the

470 selection of cultivars that are best suited to local agronomic conditions and the protection of

471 natural resources and environmental quality.

472

\section{5. Conclusions}

474 Alfalfa shows high potential as a biomass feedstock for lignocellulose ethanol production.

475 Growing season, harvest regime, irrigation and salinity influenced cell-wall constituents in the

476 stems of alfalfa. However there were few consistent effects of harvest regime on stem

477 lignocellulosic concentrations between the two years suggesting that differences in growth

478 environment between the two seasons may exert a strong influence on cell-wall composition in

479 alfalfa. Interestingly, irrigation with brackish water $\left(5.0 \mathrm{dS} \mathrm{m}^{-1}\right)$ increased theoretical ethanol

480 yields during both field seasons mainly due to a $2.1-4.1 \%$ increase in stem cellulose

481 concentrations. It appears that the eight cultivars of alfalfa we examined in this study may be

482 tolerant to moderate levels of salinity. However, further studies on the effects of salinity on total

483 stem yield and density are still required. 
485 variety also had high lignin content which may constrain ethanol yields. The Iroquois and

486 Viking cultivars had the highest theoretical ethanol yields, mainly due to the high hemicellulose

487 content of their stems. While hemicellulose is only a minor component of total stem

488 holocellulose concentrations (7.8-9.2\%), it may be important for large-scale ethanol production 489 due to a higher conversion efficiency than cellulose. Therefore selection of alfalfa cultivars for 490 the sole purpose of feedstock for biofuels should focus on those that have high holocellulose to 491 lignin ratios. 
505 Acknowledgements

506 We thank Jon Warnke and Warnke Research Services for help with experimental setup and

507 logistical support. We also thank Brock Bermel, Brandon Bohks, Bradley Clyne, Michael

508 Euerle, Josephine Hartung, Brooks Kennedy, Kayla Kiecker, Ky McCracken, Jacob Neubauer,

509 April Pressler, Amanda Schuman and Jared Tibbetts for their help with sample preparation and

510 analysis. This work was funded by the United States Department of Energy (Grant \#DE-FG36-

511 08G088156).

512

513

514

515

516

517

518

519

520

521

522

523

524

525

526 


\section{References}

Allakhverdiev, S. I., Sakamota, A., Nishiyama, Y., Inaba, M., Murata, N. 2000. Ionic and osmotic effects of NaCl-induced inactivation of photosystems I and II in Synechococcus sp. Plant Physiol. 123, 1047-1056.

Arinze, E. A., Schoenau, G.J., Sokhansanj, S., Adapa, P. 2003. Aerodynamic separation and fractional drying of alfalfa leaves and stems - A review and new concept. Drying Technol. 21, 1669-1698.

Badger, P. C. 2002 Ethanol from cellulose: a general review. In Trends in New Crops and New Uses. J. Janick and A. Whipkey (eds.). ASHS Press, Alexandria VA. 17-21.

Bauder, J. W., Jacobsen, J.S., Lanier, W.T. 1992. Alfalfa emergence and survival response to irrigation water quality and soil series. Soil Sci. Soc. Am. J. 56, 890-896.

Behr, M., Legary, S., Hausman, J.F., Guerriero, G. 2015. Analysis of cell-wall related genes in organs of Medicago sativa L. under different abiotic stresses. Int. J. Mol. Sci. 15, 1610416124.

Carlson, C. R., Cummins J.F., Diers, M.P., Dykhuizen, D.R., Poch, G., Rolling, R.E., Saari, C.T., Whitaker, O.J. 1980. Soil Survey of Freeborn County, Minnesota. United States Department of Agriculture Soil Conservation Service in cooperation with the Minnesota Agricultural Experiment Station. 30-31.

Chapple, C., Ladisch, M., Meilan, R. 2007. Loosening lignin's grip on biofuel production. Nature Biotechnol. 25, 746-748.

Deetz, D. A., Jung, H.J., Buxton, D.R. 1994. Water-deficit effects on cell-wall composition and in-vitro degradability of structural polysaccharides in alfalfa stems. Crop Sci. 36,383-388.

Downing, M., Volk, T.A., Schmidt, D.A. 2004. Development of new generation cooperatives in agriculture for renewable energy research, development, and demonstration projects. Biomass Bioenergy 28, 425-434.

Esechie, H. A., Al-Barhi, B., Al-Gheity, S., Al-Khanjari, S. 2002. Root and shoot growth in salinity stressed alfalfa in response to nitrogen source. J. Plant Nutr. 25, 2559-2569.

Guerriero, G., Legay, S., Hausman, J.F. 2014. Alfalfa cellulose synthase gene expression under abiotic stress: a hitchhiker's guide to RT-qPCR normalization. PLOS One 9, e103808.

Howell, T.A. 2001. Enhancing water use efficiency in irrigated agriculture. Agron. J. 93, 281289. 
568

569

570

571

572

573

574

575

576

577

578

579

580

581

582

583

584

585

586
Jung, H.G., Engel, F.M. 2002. Alfalfa stem tissues: cell wall deposition, composition, and degradability. Crop Sci. 42, 524-534.

Khan, M.G., Silberbush, M., Lips, S.H. 1994. Physiological studies on salinity and nitrogen interactions in alfalfa. II. photosystems and transpiration. J. Plant. Nutr. 17, 669-682.

Krogman, K. K., Hobbs, E.H. 1965. Evapotranspiration of irrigated alfalfa as related to season and growth stage. Can. J. Plant Sci. 45, 310-313.

Lamb, J. F. S., Sheaffer, C.C., Samac. D.A. 2003. Population density and harvest maturity effects on leaf and stem yield in alfalfa. Agron. J. 95, 635-641.

Lamb, J.F. S., Jung, H.G., Sheaffer, G.C., Samac, D.A. 2007. Alfalfa leaf protein and stem cell wall polysaccharide yields under hay and biomass management systems. Crop Sci. 47, 1407-1415.

Lamb, J.F.S., Jung, H.G., Riday, H. 2014. Growth environment, harvest management and germplasm impacts on potential ethanol and crude protein yield in alfalfa. Biomass Bioenergy. 63, 114-125.

Maheshwari, S. 2008. The science behing the biofuels controversy. Curr. Sci. India 95, 594-602.

Manske, L. Goetz, H. 1982. Alfalfa variety trial. <https://www.ag.ndsu.edu/archive/dickinso/research/1982/section_3/05_ALFALFA\%20 VARIETY\%20TRIAL.pdf >

McCaslin, M., Miller, D. 2007. The Future of Alfalfa as a Biofuels Feedstock. California Alfalfa \& Forage Symposium.

McKenzie, R. H. 2005. Soil and Nutrient Management of Alfalfa. Agri-Facts. Agdex 121/531-5.

Montazar, A., Sadeghi, M. 2008. Effects of applied water and sprinkler irrigation uniformity on alfalfa growth and hay yield. Agric. Water Manage. 95, 1279-1287.

Munns, R. 2002. Comparative physiology of salt and water stress. Plant, Cell Environ. 25, 239250.

Munns, R., James, A.J., Lauchli, A. 2006. Approaches to increasing the salt tolerance of wheat and other cereals. J. Exp. Bot. 57, 1025-1043.

Quiroga, M., Guerrero, C., Botella, M.A., Barceló, A., Amaya, I., Medina, M.I., Alonso, F.J., deForchetti, S.M., Tigier, H., Valpuesta, V. 2000. A tomato peroxidase involved in the synthesis of lignin and suberin. Plant. Physiol. 122, 1119-1127.

Rugagauska, A. J., Williams, C.K., Davison, B.H., Britovsek, G., Caimey, J., Eckert, C.A., Frederick, W.J., Hallett, J.P, Leak, D.J., Liotta, C.L., Mielenz, J.R., Murphy, R., Templer, R., Tschaplinski, T. 2006. The path forward for biofuels and biomaterials. Science 311, 484-489. 
602

603

604

605

606

607

608

609

610

611

612

613

614

615

616

617

618

619

620

621

622

623

624

625

626

627

628

629

630

631

632

633

634

635

636

Rock, K. P., Thelemann, R.T., Jung, H. J. G., Tschirner, U.W., Sheaffer, C.C., Johnson, G.A. 2009 Variation due to growth environment alfalfa yield, cellulosic ethanol traits, and paper pulp characteristics. Bioenergy Res. 2, 79-89.

Ruhland, C.T., Warnke, A.H., Cahlander-Mooers, A., Wood, J., Wozniak, B.M. 2011. Cellulose and lignin concentrations in prairie and wetland species: implications for feedstock in cellulosic ethanol production. Proceedings of the North American Prairie Conference 22, 176-180.

Saeed, I. A. M., El-Nadi, A.H., 1997. Irrigation effects on the growth, yield, and water use efficiency of alfalfa. Irrigation Sci. 17, 63-68.

Samac, D.A., Jung, H. J. G., Lamb, J.F.S., 2006. Development of Alfalfa (Medicago sativa L.) as a feedstock for production of ethanol and other bioproducts. In Minteer, S., editor. Alcoholic Fuels. Boca Raton, FL: CRC Press. p. 79-98.

Sánchez-Aguayo, I., Rodriguez-Galán, J.M., Garcia, R., Torreblanca, J., Pardo, J.M. 2004. Salt stress enhances xylem development and expression of S-adenoysl-L-methionine synthase in lignifying tissue of tomato plants. Planta 220, 278-285.

Sanderson, M. A., Wedin, W.F., 1988. Cell wall composition of alfalfa stems at similar morphological stages and chronological age during spring growth and summer regrowth. Crop Sci. 28, 342-347.

Serraj, R., Drevon, J.J. 1998. Effects of salinity and nitrogen source on growth and nitrogen fixation in alfalfa. J. Plant. Nutr. 21, 1805-1818.

Sheaffer, C. C., Martin, N.P., Lamb, F.S., Cuomo, G.R., Jewett, J.G., Querting, S.R. 2000. Leaf and stem properties of alfalfa entries. Agron. J. 92, 733-739.

Shinners, K.J., Herzmann, M.E., Binversie, B.N., Digman, M.F. 2007. Harvest fractionation of alfalfa. T. ASABE. 50, 713-718.

Tenhaken, R. 2015. Cell wall remodeling under abiotic stress. Front. Plant Sci., 5, 1-9.

Vadas, P. A., Barnett, K.H., Undersander, D.J. 2008. Economics and Energy of Ethanol Production from Alfalfa, Corn, and Switchgrass in the Upper Midwest, USA. Bioenergy Res. 1, 44-55.

Van Soest, P. J., Robertson, J.B., Lewis, B.A. 1991. Methods for dietary fiber, neutral detergent fiber, and nonstarch polysaccharides in relation to animal nutrition. J. Dairy Sci. 74, 3583-3597.

Vaughan, L. V., MacAdams, J.W., Smith, S.E., Dudley, L.M. 2002. Growth and yield of differing alfalfa rooting populations under increasing salinity and zero leaching. Crop Sci. 42, 2064-2071. 
637

638

639

640

641

642

643

644

645

646

647

648

649

650

651

652

653

654

655

656

657

658

659

660

661

662
Walsh, M. E., De La Torre Ugarte, D.G., English, B.C., Jensen, K., Hellwinckel, C., Jamey Menard, R., Nelson, R.G. 2007. Agricultural Impacts of Biofuels Production. J. Agr. Appl. Econ. 39, 365-372.

Wyman, C. E. 2007. What is (and is not) vital to advancing cellulosic ethanol. Trends Biotechnol. 25, 153-157. 
FIGURE LEGENDS

665 Figure 1. The percent cellulose (A), hemicellulose (B), holocellulose (C), and lignin (D)

666 concentrations and holocellulose to lignin ratio (E) for plants sampled at the full-bud and 50\%-

667 flower regimes with the corresponding treatment (rainfed, brackish water, or fresh water) during

6682010 and 2011. Values are means of the harvest regime and the corresponding treatment during

669 the 2010 ( $n=80$, white shading) and 2011 ( $n=160$, grey shading) growing seasons. Vertical error

670 bars represent \pm 1 SE. Letters $(a+b, 2010)$ and $(r-u, 2011)$ denote significant differences among

671 treatments and $\mathrm{a} *$ signifies differences between years $(\mathrm{p}<0.05)$.

672 Figure 2. Constituent analyses for plants growing under the rainfed, brackish-water and fresh-

673 water treatments during the 2010 and 2011 growing seasons. Values are means of the treatments

674 during each growing season $(n=160,2010$ and $n=320,2011)$. Letters (a-e) denote significant

675 differences among treatments $(\mathrm{p}<0.05)$.

676 Figure 3. Constituent analyses for each cultivar during the 2010 and 2011 growing seasons.

677 Values are means of each cultivar during $2010(\mathrm{n}=90$, white shading) and 2011 ( $\mathrm{n}=140$, grey

678 shading). Letters (a-d, 2010) and ( $\mathrm{r}-\mathrm{t}, 2011)$ denote significant differences among cultivars and a

$679 *$ signifies differences between years $(\mathrm{p}<0.05)$.

680 Figure 4. The theoretical ethanol yield $\left(\mathrm{L} \mathrm{t}^{-1} \mathrm{DW}\right)$ for the rainfed, brackish-water, and fresh681 water treatments during the 2010 and 2011 growing seasons. Values are means of the treatments 682 during each season $(n=160,2010$ and $n=320,2011)$. Letters (a-d) denote significant differences 683 among treatments $(\mathrm{p}<0.05)$.

684

685

686

687

688 
Table 1. Cellulose, hemicellulose, and total theoretical ethanol yields ${ }^{1}$ following Boyer (2002) for the full-bud control, saline, and irrigated treatments and the 50\%-flower control, saline, and irrigated treatments for the 2010 and 2011 growing seasons. Values represent treatment means $(\mathrm{n}=80)$ and letters designate differences between treatments $(\mathrm{LSD} ; \mathrm{p}<0.05)$ and $*$ indicates differences between years $(\mathrm{p}<0.05)$.

\begin{tabular}{|c|c|c|c|c|c|c|}
\hline $\begin{array}{l}\text { Growth Stage and } \\
\text { Treatment }\end{array}$ & $\begin{array}{l}\text { Cellulose Yield } \\
2010\end{array}$ & $\begin{array}{l}\text { Cellulose Yield } \\
2011\end{array}$ & $\begin{array}{l}\text { Hemicellulose Yield } \\
2010\end{array}$ & $\begin{array}{l}\text { Hemicellulose Yield } \\
\qquad 2011\end{array}$ & $\begin{array}{l}\text { Total } \\
\text { Yield } \\
2010\end{array}$ & $\begin{array}{l}\text { Total } \\
\text { Yield } \\
2011\end{array}$ \\
\hline Full-bud Control & $123.8^{\mathrm{abc}}$ & $114.8^{\mathrm{e}}$ & $19.2^{\mathrm{d}}$ & $19.0^{c}$ & $143.0^{\mathrm{bc}}$ & $133.8^{\mathrm{d}}$ \\
\hline Full-bud Saline & $125.0^{\mathrm{ab}}$ & $121.7^{\mathrm{c}}$ & $24.8^{\mathrm{a}}$ & $22.8^{b}$ & $149.8^{\mathrm{a}}$ & $144.5^{\mathrm{b}}$ \\
\hline Full-bud Irrigated & $121.6^{\mathrm{abc}}$ & $117.1^{\mathrm{d}}$ & $24.4^{\mathrm{a}}$ & $24.5^{\mathrm{a}}$ & $146.0^{\mathrm{ab}}$ & $141.6^{\mathrm{c}}$ \\
\hline Full-bud Average & & & & & $146.3^{*}$ & 139.9 \\
\hline $50 \%$-flower Control & $121.3^{b c}$ & $122.9^{c}$ & $22.6^{\mathrm{c}}$ & $19.3^{c}$ & $143.9^{\mathrm{b}}$ & $142.2^{\mathrm{c}}$ \\
\hline 50\%-flower Saline & $125.8^{\mathrm{a}}$ & $126.2^{\mathrm{a}}$ & $21.2^{\mathrm{a}}$ & $22.2^{\mathrm{b}}$ & $147.0^{\mathrm{ab}}$ & $148.4^{\mathrm{a}}$ \\
\hline $50 \%$-flower Irrigated & $120.1^{\mathrm{c}}$ & $124.7^{\mathrm{b}}$ & $20.8^{b}$ & $22.2^{b}$ & $140.9^{c}$ & $146.9^{\mathrm{a}}$ \\
\hline $50 \%$-flower Average & & & & & 143.9 & $145.8^{*}$ \\
\hline
\end{tabular}

${ }^{1}$ Ethanol yields are expressed in liters of ethanol per $1000 \mathrm{~kg}$ of dried biomass. 
Table 2. Cellulosic, hemicellulosic, and total theoretical ethanol yields ${ }^{1}$ following Boyer (2002) for the eight varieties we examined during the 2010 and 2011 growing seasons. Values represent treatment means $(n=90)$ and letters designate differences between cultivars (LSD; $\mathrm{p}<0.05$ ).

\begin{tabular}{|c|c|c|c|c|c|c|}
\hline Cultivar & $\begin{array}{l}\text { Cellulosic } \\
\text { Yield } 2010\end{array}$ & $\begin{array}{l}\text { Cellulosic } \\
\text { Yield } 2011\end{array}$ & $\begin{array}{l}\text { Hemicellulosic } \\
\text { Yield } 2010\end{array}$ & $\begin{array}{l}\text { Hemicellulosic } \\
\text { Yield } 2011\end{array}$ & $\begin{array}{l}\text { Total } \\
\text { Yield } \\
2010\end{array}$ & $\begin{array}{l}\text { Total } \\
\text { Yield } \\
2011\end{array}$ \\
\hline Fontanelle & $123.2^{b c}$ & $124.2^{\mathrm{ab}}$ & $20.6^{\mathrm{c}}$ & $20.6^{\mathrm{d}}$ & $143.8^{\mathrm{bc}}$ & $144.8^{\mathrm{ab}}$ \\
\hline Gold Country & $127.2^{\mathrm{a}}$ & $124.5^{\mathrm{a}}$ & $21.3^{\mathrm{bc}}$ & $20.8^{\mathrm{cd}}$ & $148.5^{\mathrm{a}}$ & $145.3^{\mathrm{ab}}$ \\
\hline Iroquois & $124.9^{\mathrm{ab}}$ & $118.9^{\mathrm{d}}$ & $24.2^{\mathrm{a}}$ & $21.9^{\mathrm{abc}}$ & $149.1^{\mathrm{a}}$ & $140.8^{\mathrm{c}}$ \\
\hline Viking 3100 & $126.1^{\mathrm{ab}}$ & $121.9^{c}$ & $21.3^{b c}$ & $21.3^{\mathrm{bcd}}$ & $147.4^{\mathrm{ab}}$ & $143.2^{\mathrm{b}}$ \\
\hline Viking 357 & $122.4^{\mathrm{bc}}$ & $123.9^{\mathrm{abc}}$ & $21.4^{\mathrm{bc}}$ & $22.8^{\mathrm{a}}$ & $143.8^{\mathrm{bc}}$ & $146.7^{\mathrm{a}}$ \\
\hline L447HD & $120.3^{b c}$ & $122.3^{b c}$ & $22.2^{\mathrm{bc}}$ & $22.2^{\mathrm{ab}}$ & $142.5^{\mathrm{c}}$ & $144.5^{\mathrm{ab}}$ \\
\hline WL363HQ & $117.7^{\mathrm{d}}$ & $123.2^{\mathrm{abc}}$ & $24.3^{\mathrm{a}}$ & $22.5^{\mathrm{ab}}$ & $142.0^{\mathrm{c}}$ & $145.7^{\mathrm{a}}$ \\
\hline Enforcer & $117.8^{\mathrm{d}}$ & $119.1^{\mathrm{d}}$ & $22.4^{\mathrm{b}}$ & $21.4^{\mathrm{bcd}}$ & $140.2^{c}$ & $140.5^{\mathrm{c}}$ \\
\hline
\end{tabular}

${ }^{\mathrm{T}}$ Ethanol yields are expressed in liters of ethanol per $\mathrm{t}$ of dried biomass. 


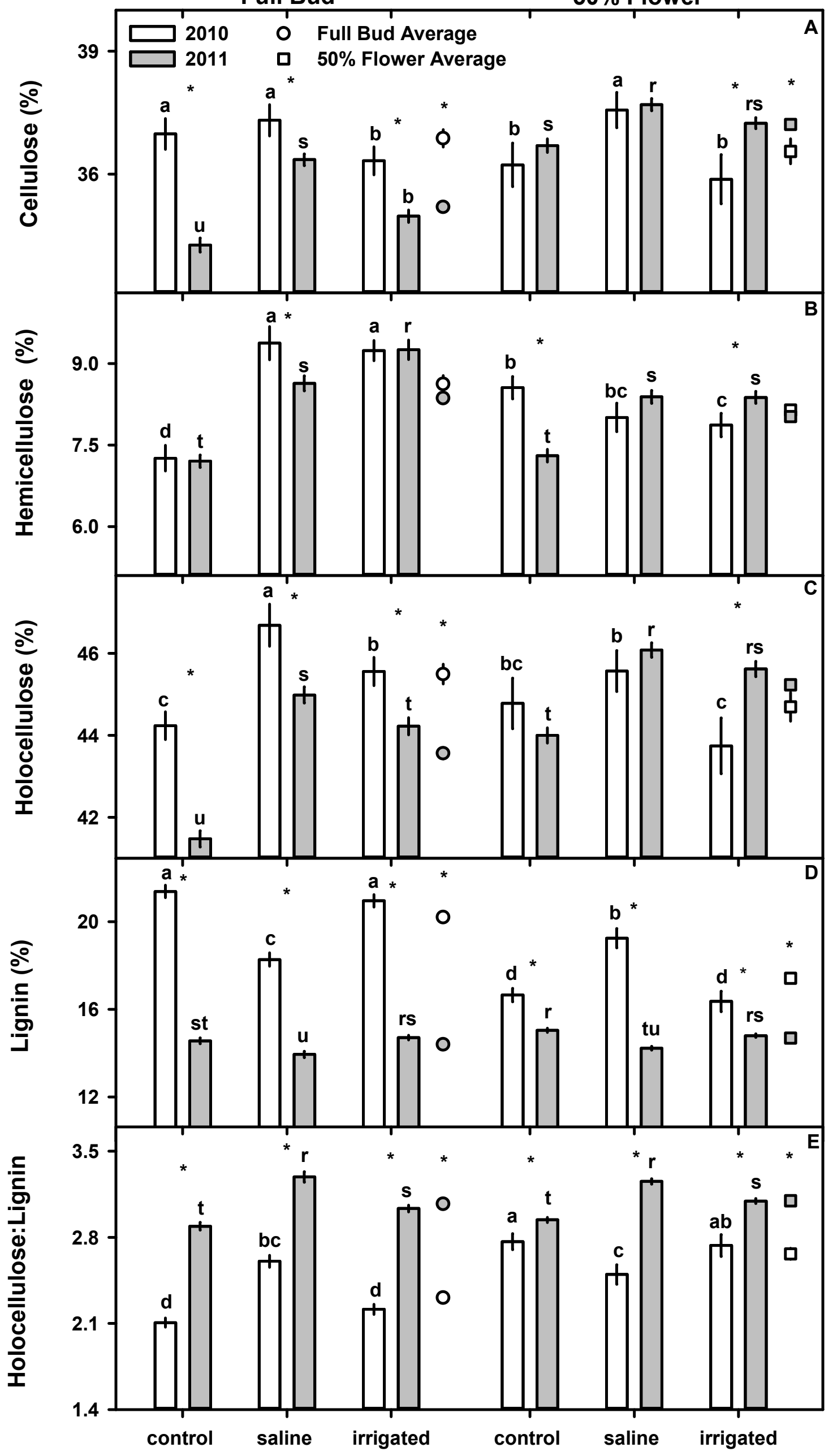

Figure 1 


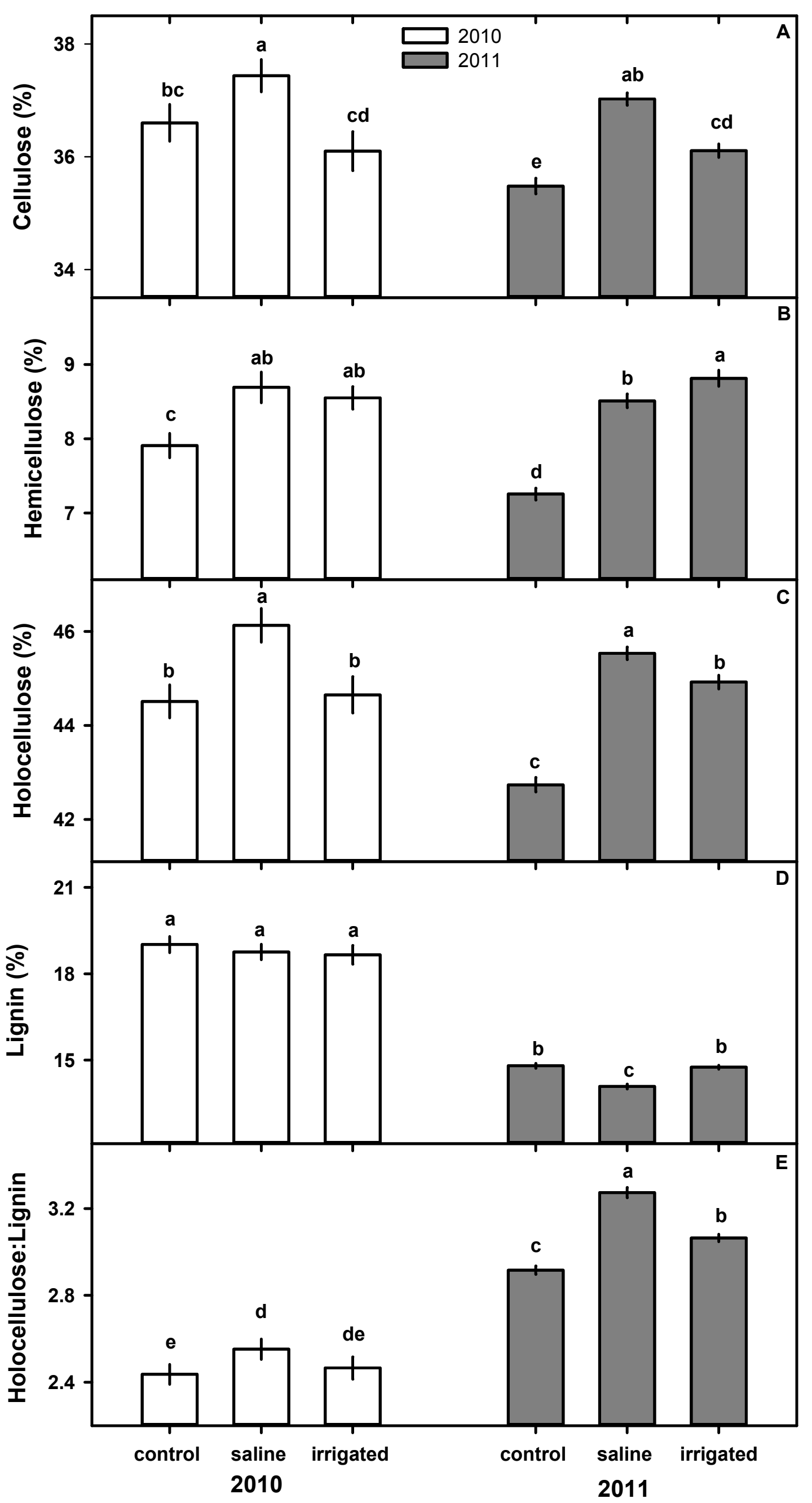

Figure 2 

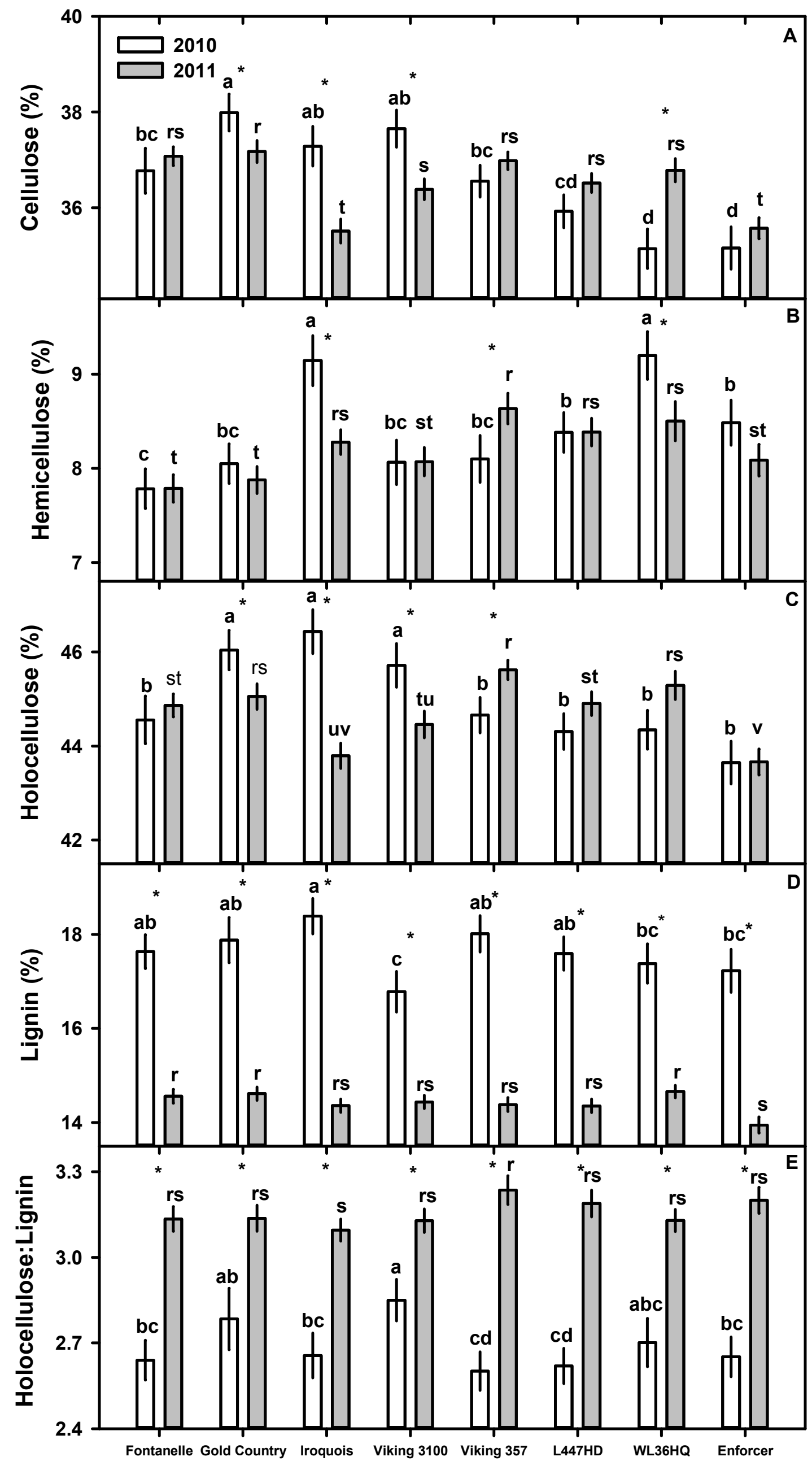

Figure 3 


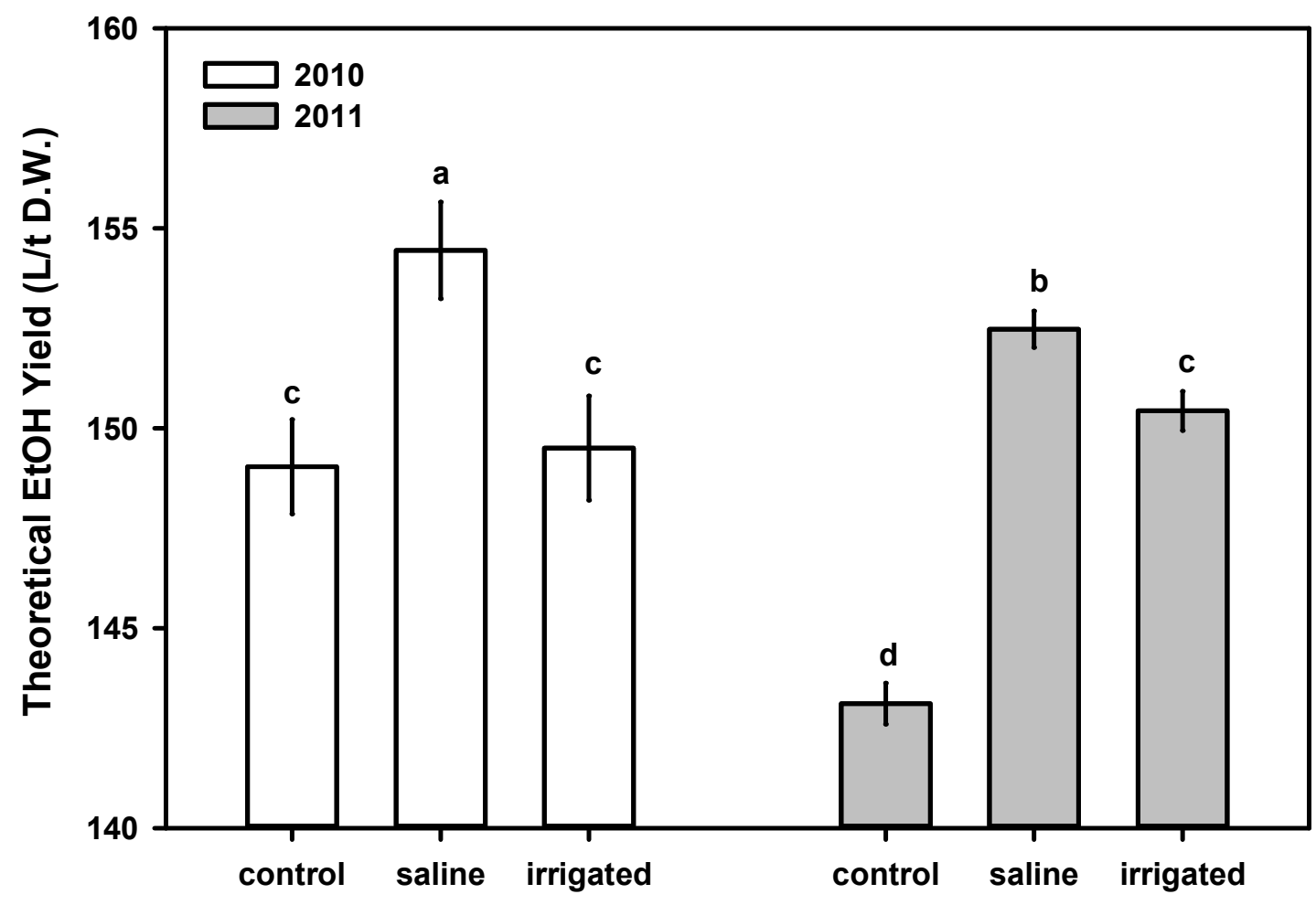

Figure 4 